\title{
Studies on Serum Haemolytic Complement and Haematological Parameters in Apparently Healthy Dromedary Camels (Camelus Dromedarius) in Northern Nigeria
}

\author{
${ }^{* 1}$ KUMSHE, H.A., ${ }^{2}$ MBAYA, A.W., ${ }^{1}$ GEIDAM, Y.A., ${ }^{1}$ BUKAR-KOLO, Y.M., ${ }^{3}$ ADAMU, Y.A and ${ }^{1}$ TURAKI, U.A. \\ ${ }^{1}$ Department of Veterinary Medicine, ${ }^{2}$ Department of Veterinary Microbiology and Parasitology Faculty of Veterinary Medicine, \\ University of Maiduguri, Nigeria ${ }^{3}$ Dept of Medicine, Surgery and Theriogeniology. Usmanu Danfodio University, Sokoto, Nigeria \\ *Correspondence: husseinkumshe@yahoo.com, Tel: + 234- 08036411956
}

\section{SUMMARY}

Studies on serum haemolytic compliment and haematological parameters in 330 apparently healthy dromedary camels (Camelus dromedarius) were conducted in northern, Nigeria. The survey was conducted in the abattoirs of three major northern cities of Maiduguri, Kano and Sokoto. The parameters measured using standard procedures were complement level via the classical pathway $\left(\mathrm{CH}_{50}\right)$, packed cell volume (PCV), red blood cell (RBC) and white blood cell counts (WBC). Mean $\mathrm{CH}_{50}$ units in the camels investigated was $360 \pm 15.8$. In addition, PCV $(32.9 \pm 1.5)$, total $\operatorname{RBC}\left(10.2 \times 10^{12} / \mathrm{L} \pm 1.2\right)$ and $\mathrm{WBC}(7.2$ $\left.x 10^{9} \pm 1.3\right)$ values were obtained. There was no significant ( $p>0.05$ ) differences between sexes and ages in all the parameters studied. The result obtained can be used as preliminary data in the investigation of the role of complement and blood cells in some immune mediated parasitic, bacterial and viral diseases of the dromedary camel in the study area.

KEY WORDS: Serum complement, Camels, Haematology, Nigeria

\section{INTRODUCTION}

The complement system has important functions as integral part of the immune system (MullerEberhard, 1986). There are two pathways namely: the classical, antibody dependent pathway and the alternative antibody independent pathway (Kathryn and John, 1993). Both pathways comprised of a group of interacting proteins, which, once activated, result in a variety of biological effects as opsonization, mediating direct lysis, solubilizing immune complexes and generating inflammation regulatory chemotactic peptides
(Frank, 1992).

Assay of complement levels in man and animals allows the clinician to asses the role of complement in disease and health (MullerEberhard, 1986; Carrol and Fischer, 1997). For instance, the classical pathway plays an important role in preventing the formation and precipitation of large immune complexes during the early stages of antigen-antibody interaction, while the alternative pathway is important in solubilization of complexes once they are formed. This role is very important in reducing immune complex mediated disease (Reid, 1988). Hypo-complementaemia has been reported in some parasitic, bacterial and viral diseases (Tabel et al., 1980; Joiner et al., 1984; Roitt et al., 1989; Authie and Pobel, 1990).

Camels are used as food and drought animals in Northern Nigeria; however, there is paucity of information on its serum haemolytic complement levels. Thus, the purpose of this study was to assess the complement levels via a classical $\left(\mathrm{CH}_{50}\right)$ pathway in apparently healthy camels to obtain preliminary data needed in the investigation of the role of compliment and blood cells in some immune mediated disease of the camel.

\section{MATERIALS AND METHODS \\ Study Area}

Maiduguri and Sokoto where phase 1 of the study was conducted lies between latitudes $11^{\circ}$ $05^{\prime} \mathrm{N}$ and $11^{\circ} 40^{\prime} \mathrm{N}$ and longitudes $13^{\circ} 05^{\prime} \mathrm{E}$ and $13^{\circ} 25^{\prime} \mathrm{E}$ within the Sahel Savannah and characterized by a short rainy season of 3-4 months (June-September) followed by a prolonged dry season for the rest of the year. Kano, where phase 2 of the study was conducted 
lies between latitude $12^{\circ} \mathrm{N}$ and longitude $8^{\circ} \mathrm{E}$, within the Sudan savannah with a slightly different rainfall pattern, characterized by a longer rainy season of 5-7 months (AprilOctober) (Udoh, 1982).

\section{Animals}

Three hundred and thirty camels were sampled. The camels examined of both sexes were adjudged to be apparently healthy, based on freedom from gastrointestinal and haemoprotozoan parasites. They have packed cell volume (PCV) of 25 percent or greater. All the camels sampled were those passed for slaughter at the government abattoirs in Maiduguri, Kano and Sokoto. Animals observed for any gross bodily abnormalities were not selected for the study. Samples were collected at weekly intervals from the beginning of October 2008 to August 2009 (covering part of the dry and wet seasons). All sera samples were analyzed on the same day of collection.

\section{Sample collection}

Each animal was bled from the external jugular vein using $17 \mathrm{G}$ needles and $10 \mathrm{mls}$ syringes aseptically. Eight ( $8 \mathrm{mls}$ ) millilitres of blood was collected from which, $2 \mathrm{mls}$ was immediately dispensed into a Bijou bottle containing $100 \mu \mathrm{L}$ of $100 \mathrm{~nm}$ of disodium ethylene diamine tetracetic acid (EDTA) solution as anticoagulant. The remaining six (6) mls of collected blood was dispensed into plain test-tube as coagulated blood. The samples were labelled and transported to the laboratory on ice.

\section{Preparation of camel anti-rabbit haemolysin}

The procedure of Meyer and Kabat, (1961) and Lachman et al. (1973) were used with slight modifications, to raise haemolysin against camel red cells. Briefly, two adult chinchilla rabbits weighing between 1.8 to $2 \mathrm{~kg}$ were inoculated intravenously with $1 \mathrm{ml}$ of camel RBC membranes (containing $2 \mathrm{mg}$ of suspension) in isotonic saline solution as described by Dodge et al. (1963). Intravenous injection of RBC membranes was repeated at 24 hourly intervals. A total of 11 injections were given. Seventy two (72) hours after the last injection, rabbit were bled and blood allowed to clot for one hour at room temperature $\left(38^{\circ} \mathrm{C}\right)$. Serum containing haemolysin was removed by centrifugation at
$5,000 \mathrm{x} \mathrm{g}$ for 10 minutes at $4^{\circ} \mathrm{C}$. Haemolysins from the two rabbits were pooled together, dispensed in $0.5 \mathrm{ml}$ aliquots into sterilized Bijou bottles, and immediately stored at $-20^{\circ} \mathrm{C}$ until used.

\section{Sample analysis}

A micro method of the standard haemolytic assay was used for the determination of serum complement level as described by Ogundele, (1998). Briefly, $50 \mu \mathrm{L}$ of 1:50 initially titrated complement dilution was pipetted into 84 wells of U -shaped bottom microtitre plates and $50 \mu \mathrm{L}$ of $5 \times 10^{8}$ cells / ml of washed rabbit red blood cells were added to each well. The plates were incubated at $37^{\circ} \mathrm{C}$ for one hour with constant shaking at 10 minutes interval after which, the sensitized rabbit red cell suspension was washed thrice with Tris-saline buffer and supernatant solution discarded. The volume of sensitized RBC was adjusted to $50 \mu \mathrm{L}$ with Tris-saline buffer and $50 \mu \mathrm{L}$ of 40 percent fresh camel serum (FCS) added into each test well and gently shaken to ensure even suspension of erythrocytes with FCS (giving a final reaction concentration of 20 percent FCS). The plates were incubated for one hour at $37^{\circ} \mathrm{C}$ with constant shaking at 10 minutes intervals and were later spurn at $200 \mathrm{xg}$ for 10 minutes. The supernatant was pipetted and transferred into flat bottom microtitre plates. The optical density (OD) reading of the released haemoglobin was read at $541 \mathrm{~nm}$. The degree of lysis (which reflects complement activity) was calculated and converted into $\mathrm{CH}_{50}$ as described by Meyer and Kabat, (1961).

\section{Estimation of haematological parameters}

Packed cell volume (PCV), total red cell (RBC) and white blood (WBC) counts were determined by the Neubauer haemocytometer method (Jain, 1986).

\section{Examination for haemoparasites}

Each blood sample was examined for haemoprotozoans by preparing thin blood smear, air-dried, fixed with methanol and stained with $10 \%$ Giemsa stain. Sample positive for any parasite was discarded. In addition, the buffy coat examination technique as described by Murray et al. (1977) was used to screen for trypanosome infection. 


\section{Examination of fecal samples}

To screen for gastrointestinal parasites, fresh faecal samples were collected directly from the rectum of the camels and subjected to floatation method using saturated sodium chloride solution as floating medium (Anon, 1986).

\section{Statistical analysis}

The data obtained were summarized as means \pm standard error and the difference between the means determined at the $5 \%$ level of significance using Chi square test (Maed and Curnow, 1983).

\section{RESULTS}

The mean total haemolytic complement level expressed as $\mathrm{CH}_{50}$ units of apparently healthy camels is presented in Table $\mathrm{I} . \mathrm{CH}_{50}$ of all the camels investigated was $357.5 \pm 16.7$ There was no significant $(\mathrm{P}>0.05)$ differences between the $\mathrm{CH}_{50}$ units of the males and females of the animals studied. Haematological values obtained from the study are shown in Table II. The mean total packed cell volume (PCV) was $33.51 \pm 1.3$ for males and $32.0 \pm 1.4$ for females. Mean total red blood counts (RBC) were $10.8 \times 10^{12} / \mathrm{L} \pm 7.2$ and $11.0 \times 10^{12} / \mathrm{L}$ for males and females respectively. The mean white blood cell counts (WBC) for males were $6.9 \times 10^{9}$ $/ \mathrm{L} \pm 6.0$ and $7.4 \times 10^{9} / \mathrm{L} \pm 5.0$ for females. There was no significant $(\mathrm{P}>0.05)$ difference between males and females or between the young ( $<12$ months) and adults ( $>12$ months) in the haematological values of all the camels studied

Table l: Mean total haemolytic complement level according to sex and age

\begin{tabular}{lcl}
\hline Parameters & No. Examined & Mean CH50 \pm S.E. \\
\hline $\begin{array}{ccc}\text { Sexes Males } \\
\text { Females }\end{array}$ & 170 & $353.0 \pm 17.0^{\mathrm{a}}$ \\
& 160 & $362.0 \pm 14.1^{\mathrm{a}}$ \\
\hline Total & 330 & $357.5 \pm 16.7$ \\
\hline Ages Young (<12 Months) & 180 & $300 \pm 17.2^{\mathrm{a}}$ \\
$\quad$ Adult (>12 Months) & 150 & $415 \pm 14.4^{\mathrm{a}}$ \\
\hline Total & 330 & $357.5 \pm 16.3$ \\
\hline
\end{tabular}

a, a Superscripts in columns did not differ significantly $(p>0.05)$
Table II: Mean haematological parameters according to sex and age

\begin{tabular}{|c|c|c|c|c|c|}
\hline \multicolumn{2}{|c|}{ Parameters Sexes } & $\begin{array}{l}\text { No. } \\
\text { Examined }\end{array}$ & $\mathrm{PCV}(\%)$ & $\operatorname{RBC}\left(\times 10^{12} / L\right)$ & $\overline{W B C\left(x \times 10^{9} / L\right)}$ \\
\hline \multirow[t]{3}{*}{ Sexes } & Males & 170 & $33.5 \pm 1.3^{\mathrm{a}}$ & $10.8 \pm 7.2^{\circ}$ & $6.9 \pm 6.0^{\circ}$ \\
\hline & Females & 160 & $32.0 \pm 1.4^{0}$ & $11.0 \pm 1.5^{\circ}$ & $7.4 \pm 5.0^{\circ}$ \\
\hline & Total & 330 & $32.9 \pm 1.5$ & $10.9 \pm 1.2$ & $7.2 \pm 1.3$ \\
\hline \multirow[t]{3}{*}{ Ages } & Young ( $<12$ Months) & 150 & $34.0 \pm 1.6^{\circ}$ & $10.4 \pm 1.3^{\circ}$ & $6.8 \pm 6.0^{\circ}$ \\
\hline & Adult (>12 Months) & 180 & $31.5 \pm 1.4^{0}$ & $11.4 \pm 1.5^{\circ}$ & $7.5 \pm 1.6^{0}$ \\
\hline & Total & 330 & $32.8 \pm 1.5$ & $10.9 \pm 1.4$ & $6.9 \pm 1.7$ \\
\hline
\end{tabular}

\section{DISCUSSION}

The study was aimed at investigating the serum haemolytic complement level via the classical and haematological parameters in apparently healthy camels in Northern Nigeria. This investigation was necessitated by the fact that most work on haemolytic complement and haematological parameters were studied in cattle and buffaloes (Bubalis bubalis) (Tabel et al., 1980) with little attention to camels. Thus, it is conceivable that there is need for a preliminary data for assessing the role of complement and haematological parameters of camels in health.

To achieve this aim, 330 healthy camels comprising of 170 males and 160 females with a PCV of $25 \%$ and above, free from gastrointestinal and haemoparasitic infections were used for this study. Mean $\mathrm{CH}_{50}$ unit of 360.0 \pm 15.8 was obtained. This value was lower than those previously reported (Olaho-Mukani et al., 1996). This may be attributed to the peculiar nature associated with studies involving serum haemolytic complement where values do remarkably fluctuate due to variation in laboratory standard and breed disposition of the animals studied.

There was no significant $(\mathrm{P}>0.05)$ changes in the packed cell volume (PCV), total red (RBC) and white blood (WBC) cell counts of the males and females camels studied. This observation corroborates earlier findings by Higgins and Kock (1984). The finding in this study suggests the need for further studies on the haemolytic complement level of different breed, sex and age in camels to give comprehensive information on generally acceptable baseline data. 


\section{CONCLUSION}

The result obtained can be used as preliminary data in the investigation of the role of complement and blood cells in some immune mediated parasitic, bacterial and viral diseases of the dromedary camel.

\section{ACKNOWLEDGEMENTS}

The secretarial assistance of Mrs. Patience S. Wakirwa is highly appreciated

\section{REFERENCE}

ANON, (1986): Ministry of Agriculture Fisheries and Food Bull No. 11: 131-132

AUTHIE, E. and POBEL, T. (1990): Serum haemolytic complement activity and C3 levels in trypanosomiasis, under natural condition of challenges early indications of individual susceptibility to disease. Vet. Parasitol., 35: 43 59.

CAROL, M. C. and FISHER, M. B. (1997): Complement and the immune response. Curri opinion in immunol., 9: 67-69.

DODGE, J. T., MITCHELL, C. and HANAHAN, D.J. (1963): The preparation and chemical characteristic of Haemoglobin - free ghost of human erythrocytes. Arc of Biochem. Biophy., 100: $119-130$.

FRANK, M.M. (1992): The mechanism by which microrganisms avoid complement attack. Current Opinion on Immunol., 4: 14-19.

HIGGINS, A. J. and KOCK, R.A. (1984): A guide to the clinical examination, chemical restrain and medication of the camel. Brit. Vet. J., 140: 485489.

JAIN, C. N. (1986): Schalm's Veterinary Haematology, $4^{\text {th }}$ Ed. Lea and Febiger, Philadelphia: 44-48.

JOINER, K. A., BROWN, E. J. and FRANK, M. M. (1984): Complement and bacteria chemistry and biology in host defence. Annual Rev. Immunol., 2: $461-471$.

KATHRYN, L. M. and JOHN, P. A. (1993): The complement system. In: Fundamental Immunol. $3^{\text {rd }}$ Ed. William, P. Raven press Ltd: 917-741.
LACHMANN, P. J., HOBORT, M. J. and ASTON, W. P. (1973): Complement Technology. In: Handbook of Expt. Immunol., 1: 216-218.

MAED, R. and CURNOW, R.N. (1983): Statistical Methods in Agriculture and Experimental Biology. Chapman and Hall, London; 1-34.

MURRAY, M., MURRAY, P. K. and MCINTYRE, W. I. M. (1977): An improved parasitological technique for the diagnosis of African trypanosomiasis. Trans. R. Soc. Trop. Med. Hyg., 7 (4): 325-326.

UDOH, R.K. (1981): Geographical Regions in Nigeria. Heinemann Education Ltd, Ibadan: 1-24.

OGUNDELE, M.O. (1998): New insight to the role of milk fat globule membrane in the sequestration of particulate antigens: Interactions with complement systems: In Proceedings of the $5^{\text {th }}$ Internet World Congress on Biomedical Sciences at McMaster University, Canada, December $7^{\text {th }}-$ $16^{\text {th }}:: 451-459$.

OLAHO-MUKANI, J. N., NJANGO M., KIMANI, J. K. and OMUSE, J. K. (1996): Studies on the haemolytic complement of the dromedary camel (camels dromedaries) I. classical pathway haemolytic activity in serum: Publication of the division of Biochemistry and Immunology, Kenya Trypanosomiasis Research institute, Kikuju, Kenya: 812-819.

MEYER, M. M. and KABAT, E.A. (1961): Complement and complement fixation. In: Expt Immunochem. Ed. E. A. Kabat M. M. Meyer, $2^{\text {nd }}$ Ed: $133-240$.

MULLER-EBERHARD, H. J. (1986): The membrane attack complex of complement. Rev. in Immmunol., 4: 403-406.

REID, K. B. M. (1988): The complement system. In: Molecular Immunology. Ed. B. D. Hames and D. M. Glover: $189-241$

ROITT, I.; BROSTON, J. and MALE, D. (1989): Complement. In: Immunology. $2^{\text {nd }}$ Ed. Gove Pub. Company: $22-25$.

TABEL, H.; LOSES, G. J. AND MAXIE M. G. (1980): Experimental Bovine trypanosomiasis T. vivax and T. congolence II. Serum levels of total protein, albumin, Haemolytic complement and complement C3. Trop. Med. Parasit. 31: 99-104. 